$\xi=-1$

\title{
Prospects of using security mechanism in the process of rehabili- tation the building sphere in Ukraine
}

\author{
Iryna Krekoten $^{1}$, Lyudmyla Svistun ${ }^{2}$, Yulia Khudolii ${ }^{3}$ \\ ${ }^{1}$ Poltava National Technical Yuri Kondratyuk University \\ ${ }^{2}$ Poltava National Technical Yuri Kondratyuk University \\ ${ }^{3}$ Poltava National Technical Yuri Kondratyuk University \\ *Corresponding author E-mail: ikrekoten78@gmail.com
}

\begin{abstract}
In this article, securitization was investigated as one of the most important sources of financing for the construction of residential real estate in Ukraine. The main purpose of the article is to explore ways to refinance mortgage loans used in the world practice for the rehabilitation the building sphere in residential real estate and to identify ways of expanding and cheapening them. The authors have found that a depository financing model uses on the Ukrainian mortgage market has significantly reduced the possibilities for its development and makes the mortgage expensive. Also, the models of the European and American mortgage markets were compared, identified the advantages and disadvantages of each model. And the possibility of using these models in Ukraine was considered. The current state of the mortgage market in Ukraine was examined. In addition, the trend of mortgage market development in a pre-crisis and post-crisis period was demonstrated in this article. Finally, the following conclusion was drawn: in order to increase the availability of mortgage loans and to rehabilitation the construction sphere, it is necessary to introduce mechanisms for refinancing mortgage loans.
\end{abstract}

Keywords: banks, housing construction, construction companies, mortgage lending, refinancing.

\section{Introduction}

Ukrainian economic system slump development in 2014-2016 caused more severe reductions in constructing sphere comparing to other industries. At present residential housing construction is carried out to less extend when compared with pre-crisis period. The main reason for such a situation is lack of available financing sources in sufficient amount and as a result of these, shortening of credit worthy demand. That is why, meeting the needs of the majority of Ukrainians in modern, qualitative and efficient housing is practically impossible. Besides, shortening the construction volumes creates negative multiplicative effect on the whole national economy. Considering this, the aim of our article is to define the ways of residential housing construction financing which can be implemented in our country under post-crisis conditions, in particular with the help of mortgage loans securitization tools.

The problem of residential housing construction financing is widely investigated in economic literature; the experts in given problem mainly focus on mortgage crediting as one of the principal sources for financing construction industry. Real estate and financial services promoting development, recovery of the stock market, mortgage lending can not only activate reforms in the economy but also gradually ensure solving housing problems of the population. The use of this tool will significantly reduce tension in the housing sector by providing an average citizen with the opportunity to acquire housing through a mortgage [1]. It should be noted that mortgage market development and globalization under present conditions create a new financial assets class, spreading of which in terms of financial deregulation have lead to nontransparency and increased risks in financial system. This particular aspect of mortgage market is investigated in the works by P.Tiwari and, M.White, [2], and Gerald F. Davis [3].

Methodology of our research included the US mortgage market analyses, as far as it was American model which proved to be highly effective and successful. American mortgage market became a real growth driver for the national economy and contributed to creating one of the highest levels of supplying the population with housing [4]. It was facilitated with mortgage loans refinancing deployment and securitized assets explosive development. Still, the given model has a range of potential threats that were especially vivid at times of the global financial crisis. We have also investigated specific aspects of European model of mortgage market as far as it revealed bigger soundness in terms of the global financial crisis $[5,16]$.

With the basis of the works by the scientists investigating mortgage market functioning in European countries $[5 ; 6]$, we have defined the most important peculiarities that have to be taken into account while implementing European experience in Ukraine. Thus the major attention is given to the possibility of mortgage debt securitization implementation in Ukraine, which proved to be an effective tool of cheapening financial resources at the real estate market and developing residential housing construction in European countries $[8 ; 18 ; 19 ; 20 ; 21]$. Extensive issuing and placement of residential mortgage-backed securities, prevailing on the market of securities issued in $\mathrm{EU}$, in future can give a push to renewing in Ukraine construction volumes at the pre-crisis level, in the way it can be seen in a number of EU countries. It is a commonly accepted practice to finance investment and construction projects mainly by means of attracted funds. As a rule, constructing firm invests its own resources at the stage of consideration and beginning the design $[6 ; 7 ; 17 ; 19 ; 22]$. 
Constructing industry reviving is of a great importance not only from the point of macroeconomic development provision view (constructing enterprises effective activity, maintenance of enterprises producing building materials, modernization of real sector of economy production facilities, development of engineering infrastructure etc.), but also reaching the point of the European social standards of living for population in terms of meeting their needs in modern, qualitative and efficient housing. Over double reduction of construction activity volumes comparing to pre-crisis level was in a great many caused by deficit of available financial resources, emerging at the Ukrainian construction market due to financial and credit market crisis. As it is known, real estate market cycles and financial and credit market cycles correlate with each other.

\section{Main Body}

\subsection{Ukrainian Construction Industry Development Tendencies}

According to statistical data, active growth in construction industry taking place from 2005-2007 due to active spreading of mortgage crediting operations, was stemmed because of financial crisis deployment and financial resources deficit, and decrease in credit worthy demand. At late 2008 constructing companies in Ukraine carried out works at the cost of 64,4 billion hryvnias, which is $15,8 \%$ less than in 2007. Building companies in only two regions, namely Chernivtsi and Sevastopol increased construction volumes by $8,6 \%$ and $3 \%$ accordingly. Construction volumes decreased in other regions of Ukraine, the biggest shortening was in Vinnytsia region $-32 \%$, Luhansk $-30,7 \%$ and Chernihiv $-27 \%$. In JanuaryJuly 2009 construction industry indices took a turn for the worse: works were carried out at the cost of 18,2 billion hryvnias, which made $45,7 \%$ of construction volumes for the same period of the previous year. Decrease in housing construction volumes was influences by reduction (2,4 times approximately) in volumes of housing brought into service by individual housing developers, percentage of which in the total amount was equal to $43,2 \%$. It should be noted that a third part of constructed housing was carried out in Kyiv and Kyiv and Lviv regions, which is an indicator of capital and credit worthy demand availability there [11].

In 2010-2016 construction market and its segments dynamics was subjected to new conditions of national economy development. A noticeable pickup of construction industry began in 2011, at the period when a short growth stage of Ukrainian economy was coming to an end. The mentioned period positive dynamics was caused by renewal of investment into construction, which lead to gradual activation of all the types of constructing works (Fig. 1).

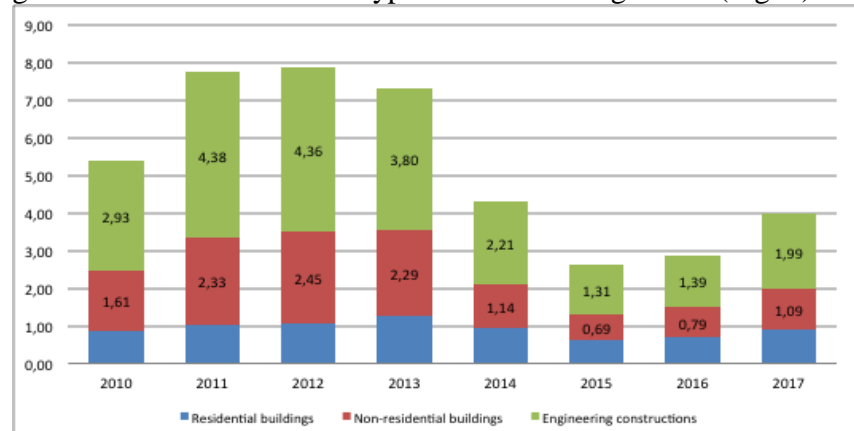

Fig. 1: Dynamics of executed construction works volumes in 2010-2017, billion USD

Source: State Statistics Service of Ukraine

The first signs of renewal were seen in the housing construction stage, activated at the beginning of 2010. It is important to note that during this period residential housing was developing at steadier rate when compared to non-residential and engineering construction.

On the other hand, constant increase in construction net cost, re- duction of long-term crediting and increase in credit interest rates as well as diverse changes in legislative regulation were significantly restricting construction market growth. Besides, that was the time of big international constructing companies leaving Ukraine [11].

In 2013 the completion of state infrastructure projects and closing up real sector investment activity worsened negative tendencies which began in the second half of 2012, and slump downturn of the whole Ukrainian economic system in 2014-2015 predicated construction industry reduction priority rates comparing to the majority of other industries.

According to official data, in 2016 the amount of housing set into exploitation in Ukraine was decreasing (Fig. 2). Besides Kyiv and Kyiv region, it was Lviv, Odesa and Ivano-Frankivsk regions that remain unchangeable leaders, with their centers together with the capital keeping first place among the cities in setting into exploitation. Although Volyn, Dnipropetrovsk, Zaporizhzhia and Kharkiv regions are leading in terms of housing supply runup: their indices grew by more than $20 \%$. It is evidence of change in the geographical structure of Ukrainian residential housing market.

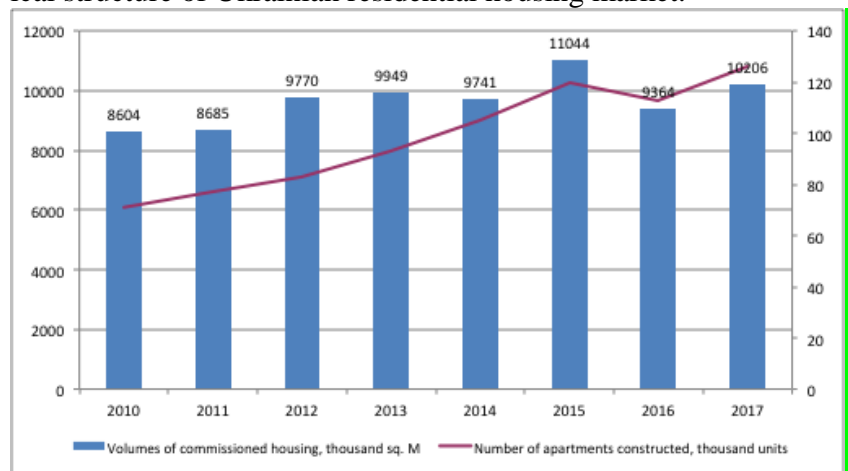

Fig. 2: The volume of the commissioning of housing area and the number of flats built in Ukraine during 2010-2017 years Source: State Statistics Service of Ukraine, NBU

The first half of 2017 demonstrated constructing market rapid growth comparing to the same period in 2016, indicating the industry run up exceeding GDP that can make it the economy growth driver. Traditionally only half of construction investments is assimilated in the of residential and nonresidential buildings segments. The other part is directed to infrastructure objects erecting. Nonresidential constructing grew by $35 \%$ comparing to the same period in 2016. Residential houses construction grew by $25 \%$. For the last 5 years prices for building and installation works have grown by 2,3 times. While hryvnias exchange rate increased by 3,3 times against the US dollar. Thus, net cost of construction in dollar terms decreased. Generally, in the first half of 2017 construction works activated in all construction spheres. Starting from the second half of 2016, investment expectations continue to remain in the positive zone, so investment growth into new projects should be expected.

Prospective of constructing industry development are rather high considering the fact that around half of housing resources in Ukraine was set into exploitation in post-war times and in the first period of industrial series houses erecting (till 1970). Today they are exhausted "Khrushchyovkas", which at the moment of erecting were located at the outskirts of the towns, while at present they happened to be in the downtowns and even in the prestigious areas That is why such areas renovation is a key problem.

In general from 2013 to 2017 the nature of capital investments into construction significantly changed: 1) their flow dynamics turned to be downward; 2) capital investments became even more directed into residential housing construction; 3) constructing activity financing at the expense of state funds and borrowed credit resources continued to reduce. In their turn, a share of enterprises and individuals own funds in the structure of capital investments were increasing. (Fig. 3). 


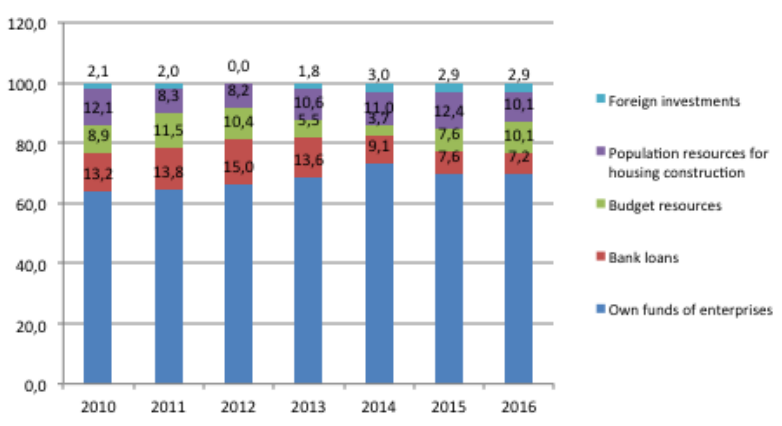

Fig. 3: The share of real investments financing sources in 2010-2016,\% Source: Ukrainian Steel Construction Centre

As seen at picture 3, the majority of capital investment into construction was carried out at the expense of constructing enterprises own funds: an average share for the whole period makes $67 \%$ from the total amount. The second most important were population own funds invested into housing construction. Their average share was equal to $10 \%$. Till the beginning of 2008 , about $70 \%$ of financing was carried out at the expense of construction developers and their investors borrowed funds. While in 2010 in Ukraine construction activity was mainly accomplished at the expense of self-financing.

As a result of construction market stagnation under currency rates going up in 2014-2016, domestic constructing companies were practically left without current assets. According to the National Bank of Ukraine data, in 2016 construction developers were credited not only by housing buyers but also by banks. It is true both for the capital city and for the regions. Large companies took the loans for up to three years term, smaller ones were given shortterm crediting from banks, which was used to maintain construction pace, if failed to sell the ready-built apartments quickly.

Thus, an important restricting factor for construction industry during all the period investigated was lack of long-term crediting both for construction products ultimate consumers and for constructing industry enterprises. Real sector crediting remained at the relatively low level taking into account a considerable overrun of credit interest rates indices over the real sector costeffectiveness.

\subsection{Ukrainian Constructing Industry Financing forms: Current Condition}

Today the majority of construction companies are using standard ways of financing which include: own funds, banking loans, investors' funds and resources of Housing Financing Fund for residential housing. But with the development of the economy, new ways of financial resources attracting appear (Table 1). It should be noted that Housing Financing Fund allows simultaneous funds attracting and finding buyers for the future residential housing objects.

For CFF of A type the of current price of construction object measurable unit, investment objects usabilities, level's and comfort index numbers are determined by builder who takes a risk of insufficiency of attracted funds for building the construction object and is responsible for setting it into exploitation despite the financing volume [13].

Table 1: Advantages and disadvantages of the financing schemes of the development projects in the construction activity $[12,2,7]$

\begin{tabular}{|c|c|c|c|}
\hline Description & Definition & Advantages & Disadvantages \\
\hline Bank Loan & $\begin{array}{c}\text { Loan capital of } \\
\text { the bank in moni- } \\
\text { tory form which } \\
\text { is transferred for } \\
\text { temporary use on } \\
\text { the basis of secu- } \\
\text { rity, repayment, } \\
\text { maturity, pay- } \\
\text { ment and proper } \\
\text { use. }\end{array}$ & $\begin{array}{c}\text { Possilining of } \\
\text { resources } \\
\text { according to } \\
\text { the schedule } \\
\text { that takes into } \\
\text { account the } \\
\text { specific needs } \\
\text { of the given }\end{array}$ & $\begin{array}{c}\text { High cost of lend- } \\
\text { ing, necessity for } \\
\text { the large amount } \\
\text { of the document in } \\
\text { the lengthy process } \\
\text { adopting decisions } \\
\text { on loans, high } \\
\text { level of the project } \\
\text { implementation } \\
\text { prior to the bank }\end{array}$ \\
\hline
\end{tabular}

\begin{tabular}{|c|c|c|c|}
\hline & & $\begin{array}{l}\text { project in the } \\
\text { amount and } \\
\text { terms. }\end{array}$ & lending. \\
\hline $\begin{array}{l}\text { Escrow } \\
\text { Credits }\end{array}$ & $\begin{array}{l}\text { Agreement in } \\
\text { consequence of } \\
\text { which one person } \\
\text { expropriates gives } \\
\text { fixed charge, rent, } \\
\text { estate property } \\
\text { and personal } \\
\text { chattels to the } \\
\text { other person for } \\
\text { the purpose to } \\
\text { sell, gives money, } \\
\text { evidence of debt, } \\
\text { document of title, } \\
\text { document of title } \\
\text { or other value to } \\
\text { the third person to } \\
\text { keep given value } \\
\text { till the happening } \\
\text { of an event or } \\
\text { execution the } \\
\text { condition when } \\
\text { such value should } \\
\text { be given to debtor } \\
\text { or lender or } \\
\text { theirs' representa- } \\
\text { tives by the third } \\
\text { person }\end{array}$ & $\begin{array}{l}\text { Investor's } \\
\text { funds are on } \\
\text { the develop- } \\
\text { er's account } \\
\text { but admitted } \\
\text { as included in } \\
\text { his assets. } \\
\text { Fast credit } \\
\text { arrangements }\end{array}$ & $\begin{array}{l}\text { The Developer } \\
\text { isn't the Escrow } \\
\text { credit funds own- } \\
\text { er; Escrow credit } \\
\text { can't be the sub- } \\
\text { ject of lenders' } \\
\text { own satisfaction of } \\
\text { requirements of } \\
\text { this account owner }\end{array}$ \\
\hline $\begin{array}{l}\text { IPO (Initial } \\
\text { Public Of- } \\
\text { fering) }\end{array}$ & $\begin{array}{c}\text { Public offering } \\
\text { for investors to } \\
\text { become company } \\
\text { shareholder first } \\
\text { done on interna- } \\
\text { tional stock mar- } \\
\text { ket }\end{array}$ & $\begin{array}{l}\text { Investment } \\
\text { rating rise for } \\
\text { getting the } \\
\text { access to } \\
\text { cheaper re- } \\
\text { sources. Great } \\
\text { allocation }\end{array}$ & $\begin{array}{l}\text { Accessible only } \\
\text { for stable and } \\
\text { widespread com- } \\
\text { panies }\end{array}$ \\
\hline $\begin{array}{c}\text { Forward } \\
\text { Finance }\end{array}$ & $\begin{array}{l}\text { Investor finances } \\
\text { the object con- } \\
\text { struction on the } \\
\text { fixed interest rate } \\
\text { and after its com- } \\
\text { pletion and rent- } \\
\text { ing buys the } \\
\text { object back on } \\
\text { previously speci- } \\
\text { fied capitalization } \\
\text { rate }\end{array}$ & $\begin{array}{l}\text { Listing in } \\
\text { stock market } \\
\text { isn't included } \\
\text { so the expens- } \\
\text { es on capital } \\
\text { raising are } \\
\text { reduced }\end{array}$ & $\begin{array}{l}\text { The scheme is } \\
\text { acceptable only for } \\
\text { development com- } \\
\text { panies which goal } \\
\text { is to sell the pro- } \\
\text { ject straight after } \\
\text { installation of real } \\
\text { estate object }\end{array}$ \\
\hline $\begin{array}{c}\text { Warrant } \\
\text { Certificate }\end{array}$ & $\begin{array}{l}\text { Agreement which } \\
\text { gives the buyer of } \\
\text { Warrant Certifi- } \\
\text { cate the right to } \\
\text { buy or sell basic } \\
\text { derivative instru- } \\
\text { ments on fixed } \\
\text { price during some } \\
\text { period or date } \\
\text { appointed in } \\
\text { advance in future } \\
\text { in exchange for } \\
\text { option premium }\end{array}$ & $\begin{array}{c}\text { Takes into } \\
\text { account inter- } \\
\text { ests of devel- } \\
\text { opment com- } \\
\text { pany, investor } \\
\text { and construc- } \\
\text { tion company. } \\
\text { Property } \\
\text { Developers } \\
\text { receive guar- } \\
\text { antees which } \\
\text { consider } \\
\text { completion of } \\
\text { construction } \\
\text { and erection } \\
\text { works on the } \\
\text { due date }\end{array}$ & $\begin{array}{l}\text { High cost. Neces- } \\
\text { sity of payment the } \\
\text { whole option } \\
\text { premium "in ad- } \\
\text { vance" in other } \\
\text { words at the mo- } \\
\text { ment of agreement } \\
\text { undertaking }\end{array}$ \\
\hline $\begin{array}{c}\text { Resources } \\
\text { of Collec- } \\
\text { tive Invest- } \\
\text { ment } \\
\text { Schemes }\end{array}$ & $\begin{array}{l}\text { CIS - it is in- } \\
\text { vestment fund or } \\
\text { share investment } \\
\text { fund which activi- } \\
\text { ty resides in un- } \\
\text { ionizing, inves- } \\
\text { tors' fund raising } \\
\text { with the goal of } \\
\text { making a profit } \\
\text { from their in- } \\
\text { vestment in the } \\
\text { others' emitters } \\
\text { securities, profit } \\
\text { participation } \\
\text { rights and real }\end{array}$ & $\begin{array}{l}\text { Profit tax- } \\
\text { haven ar- } \\
\text { rangements } \\
\text { while its } \\
\text { reinvestment. } \\
\text { Investment } \\
\text { simplicity. } \\
\text { Safety. Fund } \\
\text { profit from } \\
\text { investment } \\
\text { activities and } \\
\text { its unfavora- } \\
\text { ble profit is } \\
\text { tax-exempt } \\
\text { from enter- }\end{array}$ & $\begin{array}{l}\text { High riskiness of } \\
\text { securities services }\end{array}$ \\
\hline
\end{tabular}




\begin{tabular}{|c|c|c|c|}
\hline & estate & $\begin{array}{c}\text { prise's tax on } \\
\text { profits }\end{array}$ & \\
\hline $\begin{array}{l}\text { Construction } \\
\text { Financing } \\
\text { Fund }\end{array}$ & $\begin{array}{c}\text { Open and reliable } \\
\text { form of relations } \\
\text { between construc- } \\
\text { tion companies } \\
\text { and investors } \\
\text { during the con- } \\
\text { struction with } \\
\text { engaging of these } \\
\text { investors funds }\end{array}$ & $\begin{array}{l}\text { Scheme legit- } \\
\text { imacy. Low } \\
\text { risks of fiscal } \\
\text { uncertainty. } \\
\text { Possibility of } \\
\text { reporting of } \\
\text { data about } \\
\text { important } \\
\text { legislative } \\
\text { guarantees of } \\
\text { the rights to } \\
\text { investors }\end{array}$ & $\begin{array}{l}\text { Imbalance of } \\
\text { rights and duties of } \\
\text { developer. Impos- } \\
\text { sibility of direct } \\
\text { relations with } \\
\text { investors. Possibil- } \\
\text { ity of one-sided } \\
\text { repudiation of a } \\
\text { contract by inves- } \\
\text { tor }\end{array}$ \\
\hline
\end{tabular}

Significant push to construction industry development in 20052008 made mortgage lending market, which began to actively develop after adoption by the Verchovna Rada of Ukraine the Law "On the Mortgage" in 2003 (fig. 4).

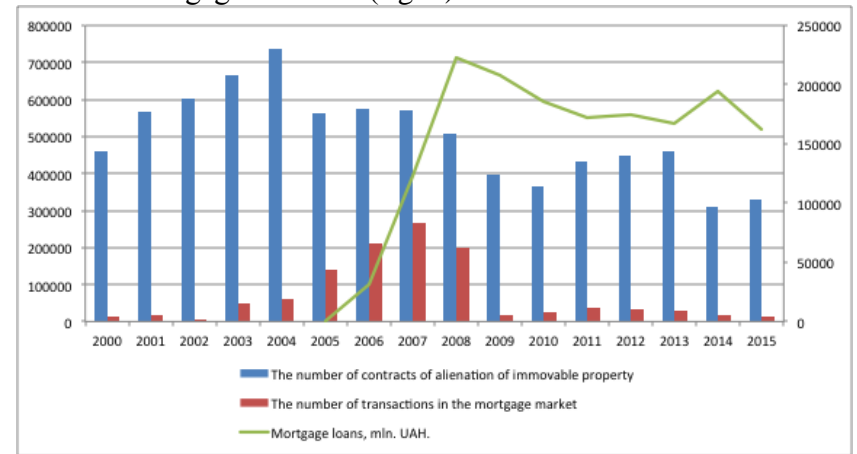

Fig .4: Indicators of the Ukrainian real estate market development and mortgage lending in 2000-2015 Source: $N B U$

Financial institutions in Ukraine obtained a tool enabling crediting individuals and legal entities for real estate purchasing [15]. Data concerning a number of real estate transactions bought with banking loans attracting proves importance of mortgage crediting development. Maximum amount of mortgage loans (267098) was given in 2007 [14]. In 2005 mortgage loans market indicated its worst result for the twelve years of its activity, 13716 mortgage loans were given, which is three times less than the initial index. Despite certain reduction of credit resources cost in the middle of 2016, their growth occurred later on, and currently the rates make average of $22-23 \%$ which cannot be compared to those in European Union (Table. 2) and in fact makes them unaffordable for the major part of our country population. Thus, renewal and further development of mortgage market and consequent activation of constructing companies activity are especially important issues for Ukraine today.

Table 2: Residential mortgage lending in EU and Ukraine

\begin{tabular}{|c|c|c|c|}
\hline Country & $\begin{array}{c}\text { Total outstand- } \\
\text { ing residential } \\
\text { mortgage lend- } \\
\text { ing (million } \\
\text { euro), III 2017 }\end{array}$ & $\begin{array}{c}\text { Gross residen- } \\
\text { tial mortgage } \\
\text { lending (mil- } \\
\text { lion euro), III } \\
2017\end{array}$ & $\begin{array}{c}\text { Mortgage } \\
\text { interest rates } \\
\text { (\%, weighted } \\
\text { average), III } \\
2017\end{array}$ \\
\hline Belgium & 229205 & 7914 & 2.11 \\
\hline Czech Republic & 39012 & 2618 & 2.17 \\
\hline Germany & 1365975 & 55700 & 1.85 \\
\hline Denmark & 245580 & 10763 & 0.94 \\
\hline Estonia & 525899 & 9117 & 1.99 \\
\hline Finland & 95672 & 7687 & 1.02 \\
\hline France & 938340 & 43663 & 1.56 \\
\hline Hungary & 13662 & 624 & 3.55 \\
\hline Italy & 373390 & 14805 & 2.02 \\
\hline Netherlands & 670785 & 25060 & 2.42 \\
\hline Poland & 91338 & $\mathrm{n} / \mathrm{a}$ & 4.50 \\
\hline Portugal & 94378 & 2132 & 1.48 \\
\hline Romania & 13948 & 764 & 3.60 \\
\hline Sweden & 403357 & 14064 & 1.53 \\
\hline United Kingdom & 1536954 & 77491 & 1.98 \\
\hline Ukraine & $\mathbf{3 4 ~ 0 0 0}$ & $\mathbf{3 7 3 9}$ & $\mathbf{2 4 , 1}$ \\
\hline
\end{tabular}

Source: European Mortgage Federation, NBU
Mortgage lending is an effective tool for construction industry development in foreign countries. In each of the European countries there is its own unique system of mortgage lending with different development levels [5]. Thus in Norway and Denmark for instance, relation between volumes of mortgage lending and GDP makes $80 \%$ and more. While in Romania and Hungary it does not exceed $15 \%$ (Fig. 5).

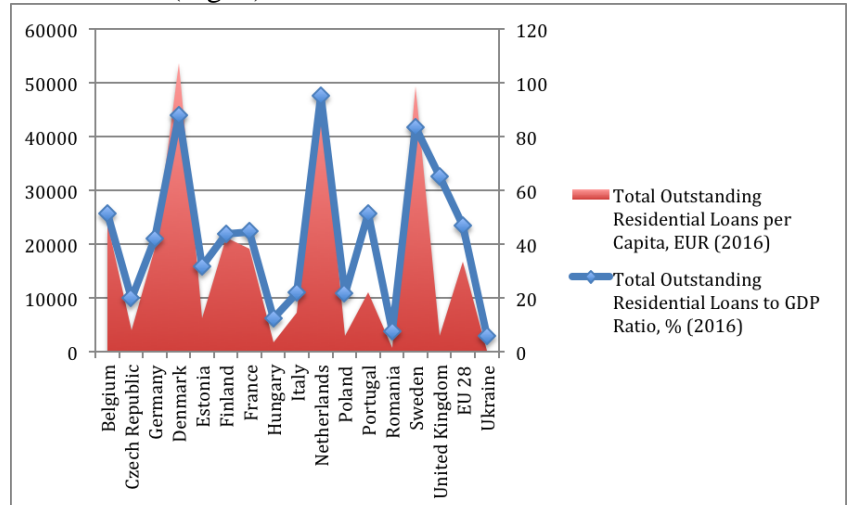

Fig. 5: Total Outstanding Residential Loans to GDP Ratio and per Capita Sources: European Mortgage Federation National Experts, European Central Bank, National Central Banks, National Statistics Offices, Eurostat, Federal Reserve, US Bureau of Census

The level of population coverage with mortgage lending varies from 3\% in Poland to 54\% in Sweden. On average in EU countries it makes $17 \%$ (Table 3 ).

Despite the existing in every European country differences, deposits are the major source of mortgage lending financing which makes $62 \%$ from all the residential mortgage loans, the mortgage securities issuing is at the second place.

Table 3: The level of the population coverage by mortgage lending [5]

\begin{tabular}{|c|c|c|c|}
\hline Country & $\begin{array}{c}\text { A share of adult } \\
\text { population } \\
\text { having mort- } \\
\text { gage loans, } \%\end{array}$ & $\begin{array}{c}\text { A share of adult } \\
\text { population } \\
\text { having mort- } \\
\text { gage loans, \% }\end{array}$ \\
\hline Austria & 25 & Slovenia & 10 \\
\hline Bulgaria & 2 & the USA & 31 \\
\hline $\begin{array}{c}\text { The Great } \\
\text { Britain }\end{array}$ & 31 & Turkey & 1 \\
\hline Spain & 32 & France & 27 \\
\hline Italy & 10 & Czech Republic & 8 \\
\hline Lithuania & 6 & Sweden & 54 \\
\hline Germany & 21 & Ukraine & $\mathbf{1}$ \\
\hline Poland & 3 & Kazakhstan & 5 \\
\hline Romania & 4 & Moldova & 1 \\
\hline Serbia & 1 & Russia & 1 \\
\hline
\end{tabular}

Taking into consideration the data presented in the table we can admit extremely low level of the population coverage with mortgage lending in Ukraine. The reasons for such a situation are widely describes in the scientific literature. Generalizing the scientists' investigations we can conclude that the current model of mortgage market in Ukraine is characterized by such features as predominantly depository financing model, dominating of universal banks, lack of the necessary infrastructure namely mortgage market specialized institutions and mortgage insurance guarantee funds, etc.

Mortgage lending development and consequent residential housing construction activation require solving plenty of tasks in various spheres, from creating guarantee system and transparent conditions for mortgage market participators to standardization and unification the procedure of mortgage lending. Though, to our mind, the priority objective is widening banks' abilities for finances attracting. It will enable mortgage lending rate declining and make it more affordable for the population. As mentioned above, a new depositary financing model is dominating in Ukraine, which considerably restricts the volumes of mortgage lending. Currently Ukrainian banking system has some positive trends, including the ones concerning the deposits amounts. Though, considering relative poverty of the majority of Ukrainian population and tradition- 
al lack of trust to banking institutions, the depository model can only provide additional financing. The main sources of financial means should include funds attracted with the help of refinancing mechanism, i.e. while using mortgage security issues.

Table 4: Funding of the mortgage market

\begin{tabular}{|c|c|c|}
\hline Country & $\begin{array}{c}\text { Total Covered Bonds } \\
\text { Outstanding, million } \\
\text { euro (2016) }\end{array}$ & $\begin{array}{c}\text { Total Residential Mortgage- } \\
\text { Backed Securities (RMBS) } \\
\text { Outstanding, million euro } \\
(2016)\end{array}$ \\
\hline Belgium & 16700 & 44817 \\
\hline Czech Republic & 13060 & - \\
\hline Germany & 207338 & 26016 \\
\hline Denmark & 386323 & - \\
\hline Finland & 33822 & 63008 \\
\hline France & 211106 & - \\
\hline Hungary & 2189 & 60816 \\
\hline Italy & 138977 & 192470 \\
\hline Netherlands & 67604 & - \\
\hline Poland & 2216 & 19237 \\
\hline Portugal & 32970 & 611 \\
\hline Spain & 232456 & 2995 \\
\hline Sweden & 222444 & - \\
\hline UK & 97127 & 112 \\
\hline Norway & 113051 & . \\
\hline
\end{tabular}

Source: European Covered Bond Council, Association for Financial Markets in Europe (AFME)

In general, development of European securitization market began at the end of 1990-s. The main driver of its developer became investors' demand, unlike the USA, with its government influence. The biggest market growth was seen in those countries where housing markets and consequently prices for housing were growing.

Together with traditional securities, collateralized debt obligation, (CDO), provided with debt obligations, started to be issued. CDO is a derivative financial instrument (credit derivative) which enables diverse debt assets pool securitization with the help of bond issuing by means of money flows generated by such assets. Depending on the basic asset type they are distinguished:

- CBO (collateralized bond obligation) - bonds, secured by other corporate bonds;

- CLO (collateralized loan obligation) - bonds, secured by banking credits portfolio;

- CFO (collateralized fund obligation) - bonds, secured by obligations of hedge funds, direct investments funds and venture funds.

European securitization market rapid grow was taking place from 1996 to 2004. In 1996 the market volume made about $€ 38 \mathrm{mln}$, in 2004 the amount of securities issuing secured by assets exceeded $€ 240$ bln. The market growth was continuing up to 2009 , i.e. till the financial crisis beginning.

At present securitization market in EU is developing slowly: issuing volumes are slightly growing, but these indices are far from pre-crisis ones (Table 5).

Table 5: Issue of collateralized securities in Europe, (billion EUR)

\begin{tabular}{|c|c|c|c|c|c|c|}
\hline & 2012 & 2013 & 2014 & 2015 & 2016 & 2017 \\
\hline $\begin{array}{c}\text { ABS (securities } \\
\text { provided by assets) }\end{array}$ & 52,3 & 71,6 & 47,6 & 64,8 & 70,6 & 59,7 \\
\hline $\begin{array}{c}\text { CDO (bonds pro- } \\
\text { vided by debt obli- } \\
\text { gations) }\end{array}$ & 0,8 & 9,2 & 14,3 & 14,2 & 21,2 & 49,2 \\
\hline $\begin{array}{c}\text { CMBS (securities } \\
\text { provided by com- } \\
\text { mercial real estate) }\end{array}$ & 18,4 & 9,5 & 6,1 & 5,9 & 3,7 & 0,9 \\
\hline $\begin{array}{c}\text { RMBS (securities } \\
\text { provided by residen- } \\
\text { tial real estate) }\end{array}$ & 119,9 & 64,9 & 110,8 & 101,0 & 119,4 & 118,1 \\
\hline
\end{tabular}

Source: AFME, ESF, Securitisation Data Report Q4 2012-2017

As the table shows, residential MBS (RMBS, Residential mortgage-backed securities) dominate at the European securitization market. ABS issuing volumes are at the second place, i.e. securities provided by assets, CDO which are used at synthetic securitization - at the third place. And only a minor part makes issuing of CMBS, securities provided by commercial mortgage loans.
Today European approaches to securitization as a factor of financial and banking instability have changed; it began to be seen as a part of anti-crisis measures. It is considered that securitization mechanism can be used to reduce credit risk and return to banks crediting activeness. Though, it should not be forgotten than it was uncontrolled usage of this mechanism that became one of financial crisis accelerators. Securitization deforms banks liquidity indices, because nonliquid credit assets are transferred to a special company, are marked off from banking balance, improving its liquidity indices. Herewith ABS assets are brought to stock market, which means that banks turn from main nonliquid shareholders to their distributors.

\section{Conclusion.}

With the regard to the above said, the following conclusions can be made. Assets securitization is one of the tools used for postcrisis renewal of European real estate market and housing construction; it can significantly widen abilities of real economy crediting and create alternative to banking lending. Using of this tool ensures reduction of bank dependency from both interbank lending and central bank refinancing. Besides, it has an important social role, which consists in ability to reduce crediting resources cost.

Thus it will boost the demand for resources from both the construction companies and the public. And the formation of significant amounts of not expensive financial resources will push for the resumption of the construction industry activity, which may be one of the catalysts of the general development of the economy. At the same time the given mechanism poses a range of potential threats, since due to it banks liquidity indicators are deformed and non-liquid instruments are spread. Securitization mechanism usage is purposeful only in terms of used assets high quality. Under such conditions there is necessity in objective estimation of investment risks and assigning credit rating to securities issued as a result of assets securitization, as well as increase in information to potential investors transparency and availability. The Basel Committee on Banking Supervision and International Organization on Securities Commissions perform promotion of the concept of effective and transparent securitization in this direction and continue developing principles on adequate assessment of carrying such operations general risks. The concept effectiveness will be investigated in our further works.

\section{References}

[1] Kharabara, V. (2017). Analysis of mortgage lending in banks in Ukraine. Baltic Journal of Economic Studies, 3(3), 59-63. DOI: http://dx.doi.org/10.30525/2256-0742/2017-3-3-59-63.

[2] Tiwari, P. and White, M. (2014). International Financial Innovation and Real Estate Market Performance. In Real Estate Finance in the New Economy (eds P. Tiwari and M. White). DOI: 10.1002/9781118836651.ch9.

[3] Davis, G. F. (2010). Not just a mortgage crisis: How finance maimed society. Strategic Organization, 8(1), 75-82. DOI: $10.1177 / 1476127009355857$.

[4] Berliner, B., Quinones, A., \& Bhattacharya, A. (2016-08-18). Mortgage Loans to Mortgage-Backed Securities. In The Handbook of Mortgage-Backed Securities: 7th Edition.: Oxford University Press. Retrieved 23 Mar. 2018, from http://www.oxfordscholarship.com/view/10.1093/acprof:oso/97801 98785774.001.0001/acprof-9780198785774-chapter-1. DOI: 10.1093/acprof:oso/9780198785774.003.0001.

[5] Aalbers, M. B. (2012). European Mortgage Markets Before and After the Financial Crisis. In Subprime Cities, M. B. Aalbers (Ed.). DOI: $10.1002 / 9781444347456 . c h 5$.

[6] Widłak, M. and Laszek, J. (2016). Milestones of Housing Finance in Poland. In Milestones in European Housing Finance (eds J. Lunde and C. Whitehead). DOI: 10.1002/9781118929421.ch17.

[7] Real Estate Financing. (2015). Wealth Opportunities in Commercial Real Estate, 119-155. DOI: 10.1002/9781119202790.ch5.

[8] Goloven, A., \& Korneev, V. (2015). Improving the system of mortgage crediting of residential real estate in Ukraine. Baltic Journal of 
Economic Studies, 1(2), 33-39. DOI: http://dx.doi.org/10.30525/2256-0742/2015-1-2-33-39.

[9] Lewin-Epstein N. \& Semyonov M. (2016). Household debt in midlife and old age: A multinational study. International Journal of Comparative Sociology, Vol 57, Issue 3, pp. 151 - 172. DOI: 10.1177/0020715216653798.

[10] Xu, Y. (2017). Mandatory savings, credit access and home ownership: The case of the housing provident fund. Urban Studies, 54(15), 3446-3463. DOI: 10.1177/0042098016676158.

[11] Dyba, M., \& Polishchuk, E. (2011). Development companies in the investment market of Ukraine (Developerski kompanii na investytsiinomu rynku Ukrainy: Monohrafiia). Kyiv: KNEU.

[12] Svystun, L. (2013). Financiang schemes of development projects in the Ukrainian real estate market (Skhemy finansuvannia developerskykh proektiv na rynku nerukhomosti Ukrainy). Economics and Region (Ekonomika i rehion), 5(42), 139-148.

[13] Zavora, T. (2013). Features of financing housing through the FFS (Osoblyvosti finansuvannia budivnytstva zhytla cherez FFB). Retrieved from http: //77.121.11.9/bitstream/PoltNTU/1042/1/ZAVORA тези 13.pdf.

[14] Lyhova, O., \& Maister, A. (2012, November/December). Mortgage lending in Ukraine: problems and prospects for development (Ipotechne kredytuvannia $v$ Ukraini: problemy ta perspektyvy rozvytku). Efektyvna Ekonomika. Retrieved November 19, 2012, from http://www.economy.nayka.com.ua/?op=1\&z=1560.

[15] Svistun, L. \& Dovgal Y. (2014). Mortgage lending in Ukraine: current problems and development factors: monogph. (Ipotechne kredytuvannia $v$ Ukraini: suchasni problemy ta faktory rozvytku). Poltava: PoltNTU.

[16] Castellani, D. (2018), Mortgage backed Securitization and SME Lending During the Financial and Economic Crisis: Evidence from the Italian Cooperative Banking System. Economic Notes, 47: 187 222. DOI: $10.1111 /$ ecno. 12096.

[17] Mattarocci G. (2015) Asset Allocation Strategy and Market Return for Real Estate Institutional Investors. In: Mattarocci G., Pekdemir D. (eds) European Real Estate. Palgrave Macmillan, London. DOI: 10.1057/9781137436122_10.

[18] Liow, K. H., Zhou, X., \& Ye, Q. (2015). Correlation Dynamics and Determinants in International Securitized Real Estate Markets. Real Estate Economics, 43(3), 537-585. DOI: 10.1111/1540-6229.12088.

[19] Noriko A. (2010). Financing through the system of securitization, targeting corporate real estate: theoretical findings best fit for eurozone economies. In 17th Annual European Real Estate Society Conference. ERES: Conference. Milan, Italy, 2010. DOI: 10.15396/eres2010_013.

[20] (2008) Asset Securitization. In: Asset Securitization im Gesundheitswesen. Gabler. DOI: 10.1007/978-3-8349-8040-3_2.

[21] Kara A., Marques-Ibanez D. \& Ongena S. (2016) Securitization and lending standards: Evidence from the European wholesale loan market, Journal of Financial Stability, Volume 26, Pages 107-127. DOI: $10.1016 /$ j.jfs.2016.07.004.

[22] Barlindhaug, R., \& Nordahl, B. I. (2018). Developers' price setting behaviour in urban residential redevelopment projects. Journal of European Real Estate Research, 00-00. DOI: 10.1108/jerer-032017-0014.

[23] Sustainable social housing: The comparison of the Mexican funding program for housing solutions and building sustainability rating systems. Héctor Saldaña-Márquez a, José M. Gómez-Soberón b, Susana P. Arredondo-Rea c, Diana C. Gámez-García a, Ramón Corral-Higuera Building and Environment, Volume 133, April 2018, Pages 103-122 ttps://doi.org/10.1016/j.buildenv.2018.02.017.

[24] Stoecker, O. (September 9, 2014). Covered Bond Models in Europe - Legal Conflict between Secured Bonds and Deposits Regarding Insolvency Remoteness and Bail-In. The Narodowy Bank Polski Workshop: Recent Trends in the Real Estate Market And its Analysis, 2013. Available at SSRN: https://ssrn.com/abstract=2841684 or http://dx.doi.org/10.21 39/ssrn.2841684.

[25] Moraru A., Kubas J., \& Istuk I. (2016). To bond or not to bond? Covered bonds reforms in central and Eastern Europe. Low in Transition Journal, Pages 10-22. 